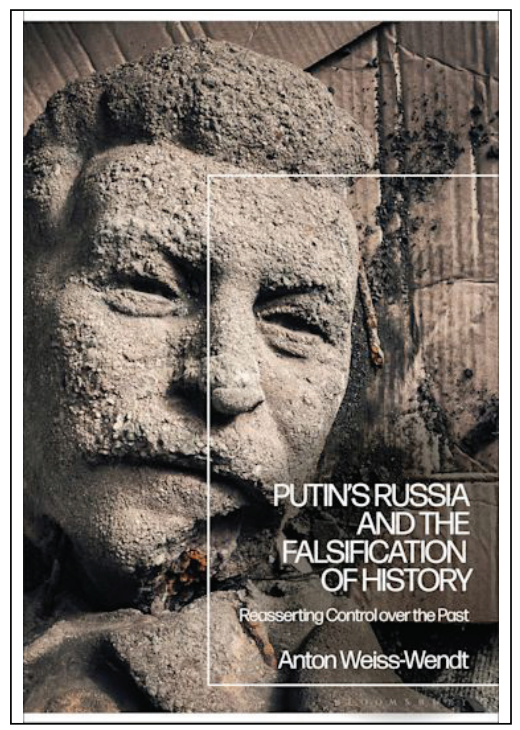

\title{
Putin's Russia and the Falsification of History: Reasserting Control over the Past
}

\author{
Anton Weiss-Wendt \\ London: Bloomsbury Academic 2021 \\ 326 sider. ISBN 9781350130531
}

Omtalt av Håvard Bækken [seniorforsker ved Institutt for forsvarsstudier, havbakken@mil.no]

Med Putin's Russia and the Falsification of History har professor Anton Weiss-Wendt skrevet en grundig og detaljrik bok om de styggere sidene ved russisk historiepolitikk under Putin. Som så ofte i russisk historiepolitisk sammenheng, omhandler boka i hovedsak hvordan historien om 1930- og 1940-tallet anvendes i dagens politiske spill, men den tar også avstikkere for å undersøke samtidens bruk av eldre historie. Boka har sju tematisk inndelte hovedkapitler, inkludert nærstudier av stalinismen, militær-patriotismen, krigsminnesmerker og Holocaust. Forfatteren går inn i et vell av kilder, inkludert russiske primærkilder, og trenger ofte dypt nok inn i dem til at selv eksperter på feltet vil finne mye nytt. Weiss-Wendt diskuterer blant annet historiekommisjoner, politisert arkivpolitikk og press på individuelle forskere som grep staten tar for å forme historiefortellingen. Han belegger også at Russland har tatt historiepolitikken tydeligere inn i diplomati og utenrikspolitikk, noe som for eksempel løftes fram i kapittelet om Holocaust. Boka framstår kompakt både i format og innhold, og har på et vis langt mer å by på enn hva sidetallet skulle tilsi.

Bokas tittel tar utgangspunkt i russiske forestillinger om at historien forfalskes som et ledd i en anti-russisk informasjonskampanje, noe Weiss-Wendt legger fram $\mathrm{i}$ introduksjonen. Tittelens tvetydighet kommer for dagen når Weiss-Wendt ganske snart snur de russiske påstandene om historieforfalskning opp ned, og hevder at det nettopp er historieforfalskning dagens offisielle Russland bedriver. Som forfatteren skriver er ikke Russlands ønske om å kontrollere historiske framstillinger noen skjult affære, men en eksplisitt politikk den politiske ledelsen går inn for med åpne øyne. Premisset for politikken vil få de fleste profesjonelle historiker til å steile: På 
bakgrunn av påståtte trusler mot nasjonal sikkerhet, tar ikke det offisielle Russland seg «råd til» et mangfold av historiefortolkninger, og ser seg derfor nødt til å verne om den «korrekte» framstillingen av historien. Ironisk nok er det ikke minst denne vedvarende insisteringen på såkalt patriotisk historieskriving som giør at den russiske fortiden er kronisk kontroversiell og uavklart.

Weiss-Wendt tar grundig for seg en mengde aktører innenfor både det offisielle og halv-offisielle Russland, og løfter dessuten fram en rekke historiepolitiske hendelser i regionene. Mangfoldet av dokumenter, personer og episoder får tilstrekkelig plass, slik at boka hele tiden frister leseren til å undersøke dem nøyere. Med sitt aktørfokus viser boka med tydelighet at Russland ikke kan reduseres til Moskva, og at regimet ikke kan reduseres til Putin. Derfor er det både overraskende og skuffende at forfatteren eksplisitt konkluderer med det motsatte - nemlig at historiepolitikken i stor grad er koordinert og forhåndsgodkjent av Putin selv. Forfatteren argumenterer for at autoritære og patronalistiske trekk ved det russiske politiske systemet har gjort dette mulig, og hevder at "alle» historiepolitiske aktører derfor søker innflytelse gjennom kontakt med regimet (s. 251-253). Disse påstandene belegges ikke, og hvor koordinert historiepolitikk Putins regime makter å føre, kan absolutt diskuteres. Dessuten fratar påstanden til Weiss-Wendt de uavhengige aktørene (se under) deres roller som historiepolitiske aktører i positiv forstand, noe jeg tviler på at forfatteren egentlig har til hensikt.

Boka har enkelte tydelig utmeislede helter, som for eksempel historikeren Jurij Dmitrijev og hans kolleger i organisasjonen Memorial, som blant annet har arbeidet mye med å dokumentere og bevare minnet om Stalins forbrytelser. Boka har imidlertid langt flere skurker, og forfatterens forakt for mange av aktørene og deres politikk skinner gjennom. Ord som «bisarr», «grotesk» og «morbid» forekommer gjentatte ganger, og forsvarsminister Sjojgu beskyldes ved en anledning for å «spy ut ... idiotiske initiativer» (s. 130). Flere av bokas overskrifter bærer tydelig preg av et normativt budskap, og forfatteren tar, etter min smak, i bruk i overkant mange generaliseringer. Å gi klart uttrykk for sitt standpunkt er ikke nødvendigvis galt i seg selv, og jeg vil tro professoren ved Holocaust-senteret er sitt valg bevisst. Men da er det uheldig at han hevder å skrive en «objektiv» analyse uten følelsesladet språk (s. 255). Personlig mener jeg at slik bitende språkføring burde være unødvendig i en akademisk bok, og Weiss-Wendt preker i hovedsak for menigheten uansett. Den lettere sarkastiske tonen i boka står i kontrast til forfatterens dokumentasjonsprosjekt, og kan i verste fall underminere det.

Snarere enn et typisk analytisk verk, framstår nemlig boka ofte som en samling av dokumentasjon for å underbygge påstanden om at mektige russiske menn manipulerer, instrumentaliserer og tidvis også forfalsker historien. Den etterlater liten tvil i så måte, for den er spekket med eksempler på at en slik omgang med historien finner sted, noe vi også vet fra tidligere analyser.

Den manglende diskusjonen med eksisterende forskning er for øvrig slående. Hvis forfatteren i større grad hadde lent seg på systematiske akademiske studier, ville 
leseren ha følt seg tryggere på at funnene hans danner et balansert bilde av situasjonen (det giør de ikke). Hvor mye kan for eksempel to militær-patriotiske pedagogiske tekster skrevet for førskolen fortelle oss om militær-patriotisme $\mathrm{i}$ barnehagene, når vi ikke får vite hvordan disse er valgt ut, hvor representative de er eller hvem som har skrevet og godkjent dem? I dette kapitlet (om militær-patriotisme) referer WeissWendt blant annet til Anna Sanina, men tar ikke hensyn til at Sanina langt på vei konkluderer i motsatt retning av ham selv - med at staten i liten grad makter å styre utviklingen, og at en ukritisk reproduksjon av sovjetiske narrativer snarere skyldes sosiologiske og kulturelle faktorer.

Vi skulle gjerne også fått vite mer om beveggrunnen til den russiske historiepolitikken, særlig i kontekst av minnepolitikken i Sentral- og Øst-Europa. Hvorfor ses den rådende historiepolitikken delvis som legitim blant den russiske befolkningen? Flere sentrale forskere på feltet ser den russiske politikken som en reaksjon på den historiepolitiske utviklingen i Polen, Baltikum og Ukraina.Vi får som lesere liten hjelp til å plassere Weiss-Wendts perspektiver blant andre analyser av russisk historiepolitikk, noe som hadde vært ekstra nyttig gitt bokas tydelige stillingtagen.

Til tross for mine innsigelser, bør det gjentas at detaljrikdommen gjør Putin's Russia and the Falsification of History nyttig for de som er interessert i russisk historiepolitikk. Den er mettet på informasjon, og forfatteren har samlet mange eksempler for ettertiden. Boka er dessuten også full av individuelle historier og karakterer som gir fortellingen farge og tekstur. Den er imidlertid rettet mot fordømmelse snarere enn forståelse av et skremmende fenomen $i$ vår samtid. 